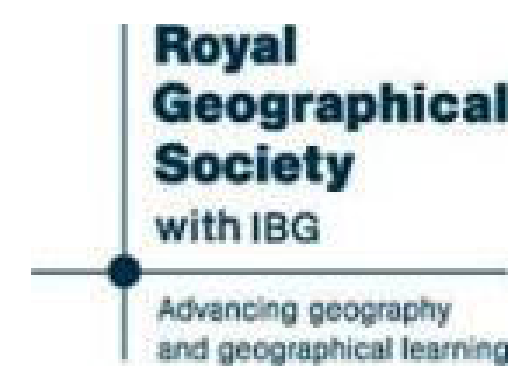

\title{
A Journey across Asia from Leh to Peking
} Author(s): C. D. Bruce

Source: The Geographical Journal, Vol. 29, No. 6 (Jun., 1907), pp. 597-623

Published by: The Royal Geographical Society (with the Institute of British Geographers)

Stable URL: http://www.jstor.org/stable/1776269

Accessed: $31 / 12 / 2014$ 14:52

Your use of the JSTOR archive indicates your acceptance of the Terms \& Conditions of Use, available at

http://www.jstor.org/page/info/about/policies/terms.jsp

JSTOR is a not-for-profit service that helps scholars, researchers, and students discover, use, and build upon a wide range of content in a trusted digital archive. We use information technology and tools to increase productivity and facilitate new forms of scholarship. For more information about JSTOR, please contact support@jstor.org. 


\section{The}

\section{Geographical Journal.}

No. 6.

JUNE, 1907.

Vol. XXIX.

\section{A JOURNEY ACROSS ASIA FROM LEH TO PEKING.**}

By Major C. D. BRUCE.

IN a paper published in the Geographical Journal, January, 1906, some instructive remarks were made on "the Present Problems of Geography." A plea was there put forward on behalf of the nonspecialist; and to travellers such as Captain Layard and myself, with aims and intentions of the best kind, yet who in so many ways lack the necessary geographical education to enable them to fulfil those aims, there is much comfort to be found in this plea. After defining geography as "the Science which deals with the forms of relief of the Earth's crust, and with the influence which these forms exercise in the distribution of all other phenomena," the author of the paper continues, "It is convenient and often profitable for a man of science to have a recognized label, but it seems to me that important advances are to be made by cultivating those corners of the field of knowledge which lie between the patches where the labelled specialists toil in recognized and respected supremacy." It is in these words that I find the only justification for venturing to attempt to lay before you the results of a journey across Asia, in the hope that we shall have been found to have cultivated, in however small a degree, some of the "corners of the field of knowledge" above referred to.

The course of the journey which you will hear of to-night may be best described as one of length without breadth. Its object was not the exploration of any one tract or country in detail, but, in the first place, the acquisition of whatever knowledge, geographical and otherwise, it was possible to collect of the regions through which we passed,

* Read at the Royal Geographical Society, January 28, 1907. Map, p. 700.

No. VI.-JunE, 1907.] 
and, in the second, the making of a more or less detailed route-survey, day by day, mile by mile, from Leh to Peking. The second, and by far the more arduous of the two objects, was only carried through thanks to the wonderful determination and pluck of our Indian surveyor, a Sikh, Lall Sing by name, lent by the Survey of India. To carry on such work as Lall Sing did daily, with frequent night observations at altitudes over 16,000 feet in Northern Tibet so late in the year as the middle of October, moving nearly every day for nine months on end, is a feat which any man, even with the reputation which those who work for the Survey of India enjoy, may, I think you will agree, well be proud of.

That portion of the continent of Asia traversed by us between Leh and Peking divides itself naturally, from the geographical point of view, into three distinct parts. The first comprises the tract between Leh in Ladak and the Kuen Lun mountains, including the Chang Chenmo and North-Western Tibet. The second, which occupied us nearly three months, was entirely made up of Chinese Turkestan; and the third includes the latter portion of our journey through China proper, which lasted three months.

Over the first portion, from Leh to the Kuen Lun, previous exploration has been chiefly confined to various surveys and attempts to obtain an alternative route between Ladak, or Rudok, and Chinese Turkestan, for such seems to have been the idea actuating some of those who have faced this inhospitable country. From the time when Dr. Thompson, the associate of Cunningham and Henry Strachey in the Ladak boundary commission of 1847 , first surmounted the Karakoram range, and that of the Schlagentweit brothers, one of whom was murdered at Kashgar, this wild region has always exercised a fascination peculiar to itself.

The country included in the second portion of our journey, viz. Chinese Turkestan, is now, after many years of comparative obscurity, once more attracting renewed attention. Fifteen hundred years ago there was a route which follows the southern border of the central desert of Chinese Turkestan, edging its way along the northern base of the Kuen Lun range. This route was then as well known, at any rate to the Chinese who controlled it, as it is to-day, and the reason is this : At the commencement of our era Buddhism first began to find its way to China from India, and ancient Chinese records prove that it was chiefly by the passage to and fro along this very route of many devotees, priests, and pilgrims that the transformation took place.

According to Chinese annals the best known of these pilgrims were two travellers of that race-Fa Hien, who passed from China to India about 450 A.D., and Hiuen Tsiang, who went and came two centuries later. Both were born travellers, and both have left records as interesting as they are authentic. About 1270 A.D. came the greatest traveller of all, Sieur Marco Polo. After traversing part of what is now Afghanistan, 

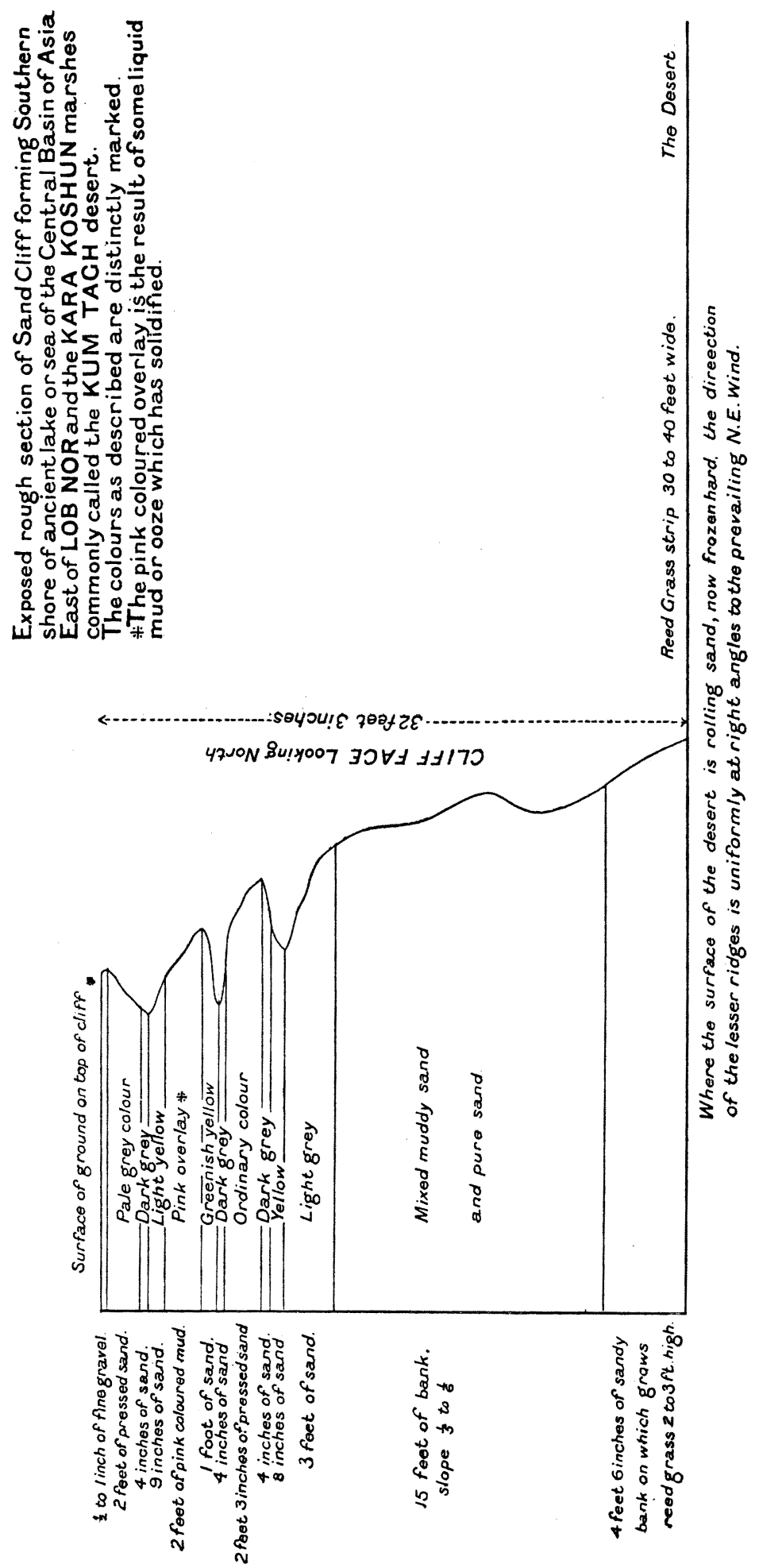

2 \& 2 
he struck down from Badakshan to Kashgar, and continued eastwards through Khotan, Kiria, and Lob Nor to Sachu-by our very route. The journey ended in his case at Shangtu (the then summer residence of Kublai Khan), 300 miles north of Peking, outside the Great Wall. In modern times the names of Prjevalsky, Roborovsky, Kozloff, as well as other gallant Russian explorers, are intimately associated with southern Chinese Turkestau. Another famous European traveller, Sven Hedin, it need hardly be said, has made his name a household word throughout the whole central desert basin. And the names of four intrepid Frenchmen, Bonvalot, Grenard, Dutreuil de Rhins, and Prince Henri d'Orleans, will always be connected with that region. Of English men and women, Captain Deasy, Mr. and Mrs. Littledale, Bower, and Malcolm are well known among determined explorers who have passed that way; and Dr. Stein, the eminent archæologist, is even now continuing those fascinating explorations which have already done so much to confirm and explain early Chinese records.

The third part of our journey was through China proper. Although it might seem as if that portion should be by far the best known of all, curious as it may appear-this is not the case. The route from Chia-yu-kuan, the ancient north-west "gate" of China, where in early times all embassies from the west were forced to await the pleasure of the mighty emperors of Cathay, up to Lan Chou, the capital of Kan-su province on the Yellow river, has not been traversed by more than a dozen Englishmen in the last fifty years. Of that number, the name of Colonel Mark Bell stands out pre-eminently. From Lan Chou to Tai-Yuan Fu, the route we followed across East Kan-su, Sheu-Hsi, and Shan-Hsi provinces to Peking, though comparatively close to civilization, is little known, for in not a few villages entered we were told that Europeans had never before been seen.

This, in brief, is an outline of the whole journey, and I will now endeavour to describe in some detail the leading physical features of the country along our route.

Leh, the capital of Ladak, is well known as the starting-point of, or the goal for, most Central Asian expeditions. It is here that caravans must be made up; food, animals, and men bought and hired; and it is not until Leh has been left behind that the traveller feels that he has cut the painter which has hitherto tied him to civilization.

From Leh to the Tibetan border, including the Chang Chenmo, the country is, comparatively speaking, well known. After surmounting in succession three high passes, the Chang La of 17,000 feet, the Masemik La of 17,600 feet, and the Lanak La of 17,750 feet, the Tibet border is reached. Two out of the three passes, though high, present no difficulty, when as we crossed them there was no snow. How simple the passage is may be imagined when it is stated that, riding on in advance of the caravan, I arrived at the summit of the Masemik La without any idea 
that the top of the pass had been reached. On entering Tibet proper, very little change in the aspect or physical character of the land is to be found. As in the Chang Chenmo, so in Tibet, the same open undulating valleys have to be crossed. Common to both sides of the border are the high plateaux, whose surrounding ranges reach over 17,000 feet, the dividing passes, and the trickling streams, which so rapidly disappear into the thirsty soil. One new feature is met with in the lakes, some of which are fresh, others distinctly salt. There are also many ancient lake-beds plainly marked, where the evidence of previous glacial action may usually be traced.

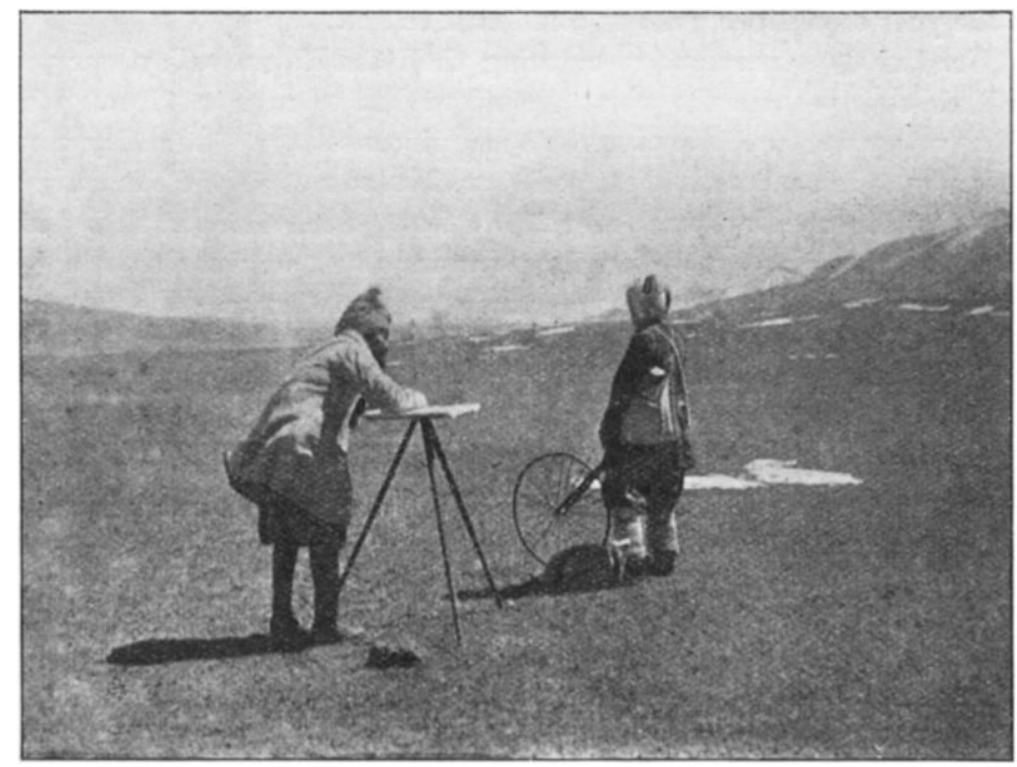

SURVEYOR LALL SING AND RAI SAHIB AT WORK ON THE TOP OF LANAK LA, 17,750 FEET.

Of vegetation in North-West Tibet there is no sign save two or three kinds of poor grass, and the "boortsa" so necessary for fuel. Animal life, though at first common, practically disappeared as we drew up to the southern side of the Kuen Lun range. Tibetan antelope covered some of the less inhospitable valleys, and kyang, the wild ass, were not infrequent. During the whole of our stay in Tibet, only one wild yak was seen, and he, unfortunately for himself, paid for the meeting with his life, as meat that day was an absolute necessity for the caravan. Of the human race or its habitations we found no sign. From the day the Tibetan border was crossed until the gorges of the Kuen Lun had been partly passed, no trace of human beings was seen, not even a black tent used by the nomads who roam the country farther south. 
From the description I have given you, it will not be hard to imagine the wearying monotony of this lonely land, and it might be supposed that Nature would have taken little pains to hedge it off from the neighbouring world. But this is far from being the case. On the northern side she has planted, in the shape of the dreaded Kuen Lun mountains, such a barrier that even the daring Russian explorers already alluded to were fain to allow themselves baffled in their attempts to find a feasible route other than the one we used.

Upon the immediate southern side of the Kuen Lun we were compelled to halt to refit and rest our animals in the only possible spot, known to the natives of Polu as the Baba Hatten valley, where so late in the year some little grazing could still be got.

For two days previous to entering the Baba Hatun valley, our way had lain over perhaps the worst ground we had to cross in Tibet. West of the valley we were following ran a magnificent range of eternally snowclad mountains, whose highest peaks, which later form one boundary of the Baba Hatun valley, reach over 21,000 feet. Such a landmark do these form that, though no new discovery was involved, we felt that as a geographical feature they ought to carry a separate name. We therefore took the liberty of giving them that of the Curzon range. Opposite to this latter, on the north-east side of the same valley, stands a wonderful group of rugged peaks and ridges also covered with eternal snows. Both offer on either hand as grand and awe-inspiring a view as the human eye could wish for. We again felt that such a unique mass of peaks deserved recognition and a separate entity, so took the liberty of giving it the name of the Kitchener group.

Leaving the Baba Hatun valley by a difficult pass called the Ak-Su La, we camped the next night but one on what is known as the Gu Gut plain. This is a wide open expanse, some 18 miles in length from east to west, with a greatest breadth of 6 to 7 miles from north to south. It is surrounded on all sides by high rugged ranges, some of whose snowclad cliffs reach over 18,000 feet. They afforded a magnificent view as the sun gained power at midday, lighting up their needle-like peaks in all the wonderful purity these fascinating snow-fields present.

Reference has already been made to the prevalence of old lake-beds in this portion of north-west Tibet, and the Gu Gut plain presents as reasonable an example of the physical geography of these on a larger scale as any. In extent, some 18 miles by 7 , the plain is bordered on its northern sides by main ridges of the Kuen-Lun range, which reach over 17,000 feet. Both at the east and west ends the surrounding mountains are lower. The western half of the plain differs entirely in character from the eastern. The former is flat gravelly shingle, rising gradually north and south to the mountains on either side. The eastern portion is not flat, but consists, on its southern side, of a series of ridges and hollows running in all directions, most distressing to pack-animals. 
These ridges vary from 20 to 60 feet in height, occasionally bursting into small hills running up to 100 feet above the plain. Both hollows and ridges are thickly sown with an outcrop of volcanic-looking black rock, which makes progress by no means easy.

On the south side of the plain lie three small lakes, the largest some 3 miles by 2 in area, and these are separated from one another by as much as 4 miles in the case of the two most eastern lakes. Ulug Kul, the first lake, so called by Deasy-our guide knew no name-is salt, and on October 15, though at an elevation of 15,200 feet, it was quite free from ice. Atchik-Kul, the second, at its eastern end, tasted sufficiently salt to be unpleasant to men. The animals, however, drank it greedily,

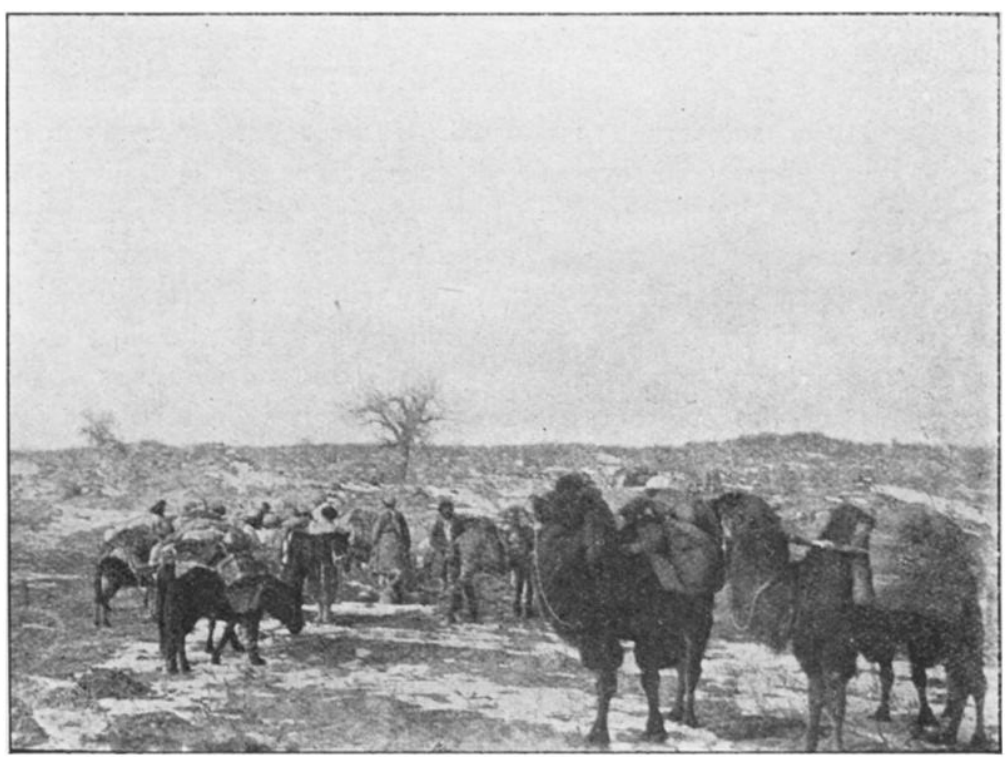

NEAR LOB NOR. MIDDAY REST AT A WATER-HOLE.

not having had any water the previous day. In contrast to Ulug Kul, this lake was frozen almost completely over. At the west end, where we subsequently camped, the water from a channel connected with the lake was quite sweet. All the lakes are either shrinking, which does not appear probable from the surrounding indications, or at. other seasons must be 5 or 6 feet above their then level.

The following day we crossed what has all the appearance of an old lake-bed, as we made for the mountains forming the northern border and barrier of the plain. In this plain and rising above these channels in the dry pond-like beds are irregular-shaped pillars and mounds, showing in places what would appear to be an older level of at least 
15 feet above the present one. From the general aspect of the southern surface of the plain sufficient indications are found to show that the whole lower side of the Gu Gut plain may once have been one large lake. How long ago, if ever, is a matter for the specialist to decide.

From the northern edge of the plain the actual passage of the Kuen Lun mountains commences. This passage occupied us five days, and we covered just over 30 miles in transit. It was $2 \mathrm{p} . \mathrm{m}$. by the time we had climbed the first pass out of the Gu Gut plain, and much too late at that season of the year to commence such a descent as that which lay before us. This pass was not that made use of by Deasy, as, our guide being most uncertain about any possible passes, we had ourselves pushed ahead, and Captain Layard, Lall Sing, and myself climbed a pass the caravan were afterwards unable to negotiate. Upon the north side the snow lay 18 inches to 2 feet deep, and there a wind raged which was, even for Tibet, more cruel than usual. After rejoining the caravan, the view which met our eyes as we gazed throngh the falling snow northwards into and over the Kuen Lun, was one neither my companions nor myself are ever likely to forget. Below and on three sides of us, stretching apparently without end, lay the wildest and most forbidding jumble of mountain ranges, peaks, and gorges imaginable. Of all shapes-crossing and recrossing in every direction, needle-pointed, flat, or rugged and broken, they had only one common feature, and that lay in their apparently inaccessible nature. There was, however, no time to waste, whatever doubts for the moment crept through our minds, it was imperative to go on, so we commenced the first descent down a slope like the side of a house, full of holes and boulders, and over the knees of the animals in snow.

For the next four days we struggled down a succession of watercourses and narrow gorges one after another, making sorry progress at times, but always in the right direction. The main gorge, known to the people of Polu at its northern end as the Zubéshie gorge, was more like a gigantic railway cutting winding through solid rock than anything else, the sides frequently sheer for hundreds of feet on either side, the bottom just sufficiently wide for a frozen brook a few yards in breadth. Into these gorges the sun rarely penetrates, and at night, when the moon is overhead, few more weird and desolate scenes can be imagined.

Though of no importance geographically, it may be of interest, perhaps, in order to show the difficulties of progress, to state that on one of the four days the caravan could only cover $1 \frac{1}{4}$ mile, and this took over four hours, at the end of which time men and animals were quite exhausted from constantly unloading and reloading every single pack. Another day 7 miles was the result of nearly ten hours' severe labour. In fact, had not the Beg, or local headman of Polu, sent out 
a party of men and donkeys to help us the last day, in all probability most of our animals would have left their bones among the mountains.

Of vegetation in the Kuen Lun there is practically none, and it was the want of even such miserable grass as had been scarce enough in Tibet that brought our animals to the state they had reached when we received help from the people of Polu. As we descended, the physical character of the surrounding mountains gradually changed.

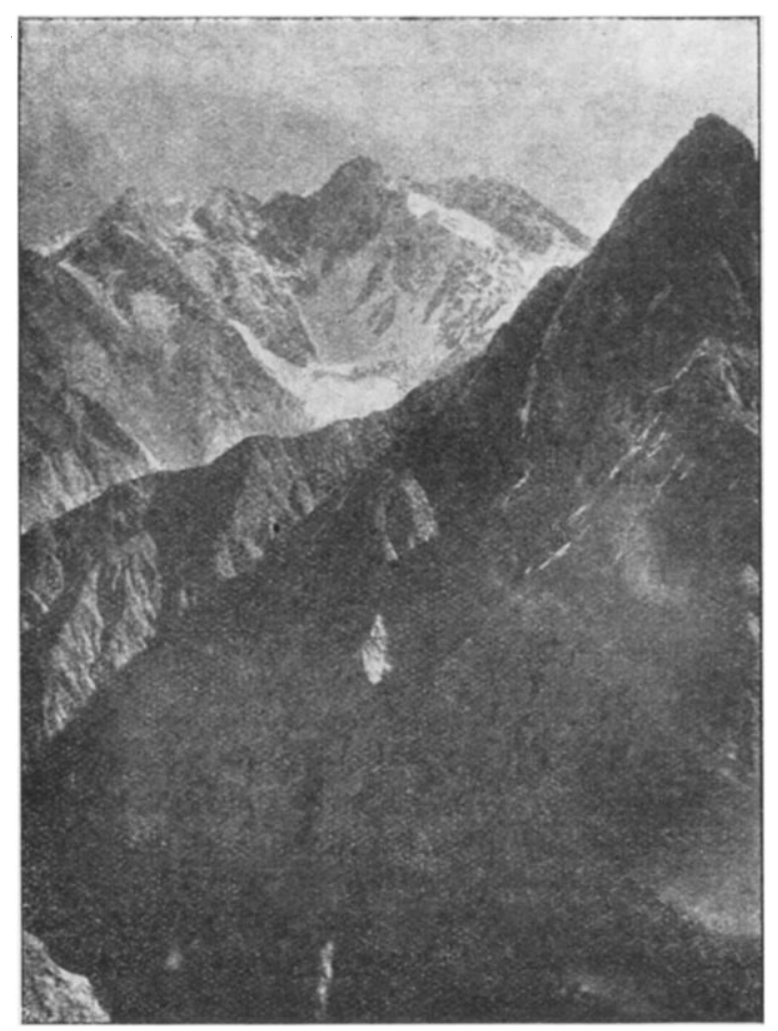

VIEW OF MOUNTAIN PEAKS FROM THE FIRST PASS INTO THE KUEN LUN RANGE.

Slaty deposits replaced pure rock, while the lower spurs become shaly soft grey earth which the wind carries in clouds, causing a constant haze. Below 10,400 feet ice on the streams ceased, and between 10,000 and 9000 feet the first sign of vegetation in the shape of a few rushes, a few withered briars, and some wild clematis became apparent. It is difficult to refrain from smiling, even now, when one recalls our excitement on reaching a turn where the last bit of gorge opened out into something of a valley, for there in the distance was to be seen one 
solitary stunted tree. It was the first we had met since leaving the Indus valley.

Clear of the gorge, the character of the country undergoes a startling and rapid transformation. Instead of the rock cutting and perpendicular cliffs, the track descends into rolling dust-coloured hills and open downs at a height of 8400 feet. These are covered with a small close-growing vetch, which in the spring probably affords excellent grazing. Not a vestige of trees, grass, or other vegetation is to be seen except this vetch. At a little distance away from the mountains and entrance to the gorge, the sudden geological change is still more apparent. The last jagged range, snow-clad throughout most of its height, gives way, almost as though in one step, to dust-coloured hills 2000 feet lower in altitude. These in their turn, as we descended after leaving Polu to Kiria, merge very gradually into rolling sand-hills, and our track passed through dunes and swelling hillocks of the same kind until the fertile oasis round Firia is reached.

In discussing the loess formation of Northern China, Richthofen has traced its limits as far as the country through which he himself had travelled, and he remarks, "I do not positively know how far it extends in the direction of Central Asia." At the time of our passing Polu, I was impressed with the similarity in the constitution of the hill country immediately adjacent to the mountains to that of loess, and after travelling for months through the great loess country of Northern China, my impression is confirmed. It may be thought that the loess formation is not usually found at such an elevation, but Richthofen has also shown that " the difference of level of the places where loess occurs is truly remarkable. Where," he writes, "its hills fringe the plain of the Yellow river, they rise only a few hundred feet above the level of the sea. But in climbing up to higher regions, one never loses sight of the yellow soil. In Shan-Hsi," he continues, "I found it largely predominating over everything else at altitudes up to 6000 feet, and met it in many places of greater elevation on the Wu-tai Shan at 8000 feet. Where it adjoins a mountain range, deep cuts will expose layers of rocky débris intercalated more or less frequently between those of loess."

About the origin of the loess formation itself, opinions once certainly varied. Whether this is still the case I am unable to say, but our own experience, for what it is worth, goes to uphold the theory that the loess formation is not stratified, and has a tendency to vertical cleavage; also that it is not of subaqueous, but of subaërial origin.

Before passing on to the second portion of our journey, the country embraced under the name of Chinese Turkestan, a few words may be of interest concerning the gold industry of the Kuen Lun. During our struggle through the mountains we had been overtaken by two small parties of men, found later on to be residents of Polu and Kiria, the last of the gold-seekers who had proceeded into the mountains in the spring 
of the year. We had noticed, all along the Zubéshie gorge, traces of their work in the shape of numerous "pockets," mostly disused. Some of these were to be seen in inaccessible-looking spots, up side ravines, and even high up in the faces of the almost sheer cliffs. The name "Zubéshie" means gold extracting, and, judging by the traces of workings to be seen, the name appears aptly chosen. The industry is carried on by natives of Polu and Kiria, whose custom it is for parties of three to five men to go up into the mountains in the spring, carrying with them only the absolute necessaries of life, and remaining just so long as they can make their provisions last, or until the approach of the winter and the snow drives them down again. Donkeys are occasionally taken to carry the small packs, but in most cases each man shoulders his own. A very hard life it is, and the attraction must be strong. East of Kiria, all along the northern base of the Kuen-Lun, gold is worked at intervals, to which reference will be made further on in this paper.

At Kiria the ancient Buddhist high-road previously mentioned is reached on the borderland of the Takla Makan desert, and the traveller finds himself on the edge of that wonderful Central Asian basin, which stretches for a distance of 2500 miles, from the Alai mountains as far east as the western slopes of the Khingan range in Manchuria.

In spite of what has already been done here in the way of exploration, it is more than possible that we are only beginning to unravel many of the archæological and historical mysteries connected with a former and far more flourishing state in the western half of this vast area. Few more fascinating scenes for such work are to be found in the present day. Unfortunately, China, which from its past history, and, in spite of Western criticism, its present wonderful state of general civilization, ought to be a subject of interest, especially to our countrymen, is even now a sealed book to the great majority. Why this should be so it is difficult to imagine. One reason, perhaps, lies in the diffculty-nay, almost impossibility to dwellers in Europe-of becoming acquainted with either its present or past records. Intimately connected as these records show China to have always been with the middle East, even as early as the first century, we in Europe have little knowledge of them, and until it is more widely realized how close this connection was with our own great Indian empire, and that almost entirely by means of the ancient route of which $I$ am endeavouring to give you some idea to-night, interest in the early civilization of China, and from that in its latter history and future, will, I fear, be confined to a very limited number of inquirers.

The town of Kiria has been identified with the Pein of Marco Polo, who passed through it about A.D. 1274. From Kiria eastwards to the border of China proper, there were in the past two main routes. From Kiria to Chakalik, some 60 miles south-west of Lob Nor, one track goes almost in a straight line east-north-east down the Cherchen river. 
The second, after leaving Kiria again, leads back to the base of the Kuen Lun mountains, and proceeds along the foot of the lowest spurs of the Altyn Tag to Chakalik. Historically, the former is of most interest, as it leads past the sites of various now buried cities, and undoubtedly is the former pilgrim route, but for other reasons we chose the mountain track after passing the town of Nia.

From Nia our next halt of any interest was at Sorghak, or, as it is locally pronounced, Sorrrăk, which may be said to be the centre of the gold industry of this district. Though figuring in European maps, Sorghak is merely a collection of wattle-built semi-underground huts, dug in the soft loess soil. Some are regular caves. A more squalid place it would be hard to find; it has all the appearance of the mining camps which Bret Harte once familiarized us with, lack of water and an allenveloping dust being its chief characteristics. The gold is worked by sinking narrow circular shafts, varying from 40 to 100 feet in depth. At the bottom of these a low tunnel is made at right angles to the shaft, 3 to 4 feet in height, and from $1 \frac{1}{2}$ to 10 feet in width. The tunnel is dug through shaly sand and gravel, in which occasional rock outcrops. Ten to twelve men, women, and children work each hole. Some of them handle the rickety windlass by which one is lowered into the pit, others pick out the soil at the bottom of the tunnel, while the remainder sift it over when it reaches the surface. Owing to the absence of water, the soil is not washed, but winnowed on exactly the same lines as is grain throughout the East. The final process consists in spreading the residue of the already winnowed soil on felts, then carefully blowing each handful over in search of gold. A more primitive method of extracting the most valuable metal in the world could not be invented. That which their forefathers, the Mongol Kalmacks, who are said to have first worked this district, did a hundred years ago, so the native Turki does to-day. What result might be obtained by the application of European methods to the Kuen Lun industry, I am unable to state with any exactitude. Though an exceedingly interesting question, it is perhaps one more suitable for the gentlemen who attend meetings east of Temple Bar than for those who have honoured me to-night.

Beside gold seeking, this portion of Turkestan boasts few industries. A certain amount of "charras," the hemp which is the main article imported by Central Asian traders via Yarkand and the Karakoram route to India, is grown in the bigger oases, but the other articles which go to make up the straggling trade that route enjoys, such as felts, embroideries, silk for underwear, and skins, chiefly come from the neighbourhood of Khotan, Yarkand, and Kashgar.

In vegetation the oases are exceedingly rich. As fine fruit, grapes, apricots, melons, and apples are grown as any in Kashmir, and Indian corn thrives in all of them. 
One of the most striking physical features of this district may be studied in the numerous mountain streams and small rivers which descend from the Kuen Lun northern slopes, all to be absorbed sooner or later by the remorseless sands, against which nothing in nature seems able to compete. Between Sorghak and Achan, a hamlet from whence we again turned north towards Cherchen, these streams occur almost every few miles. Alike in general character, varying only in size, the description of one is that of all. At the immediate foot of the lower mountain slopes the stream has usually cut for itself a deep rugged channel with frequently almost perpendicular sides. In height the latter vary from 60 to 200 feet, and in the case of the bigger streams

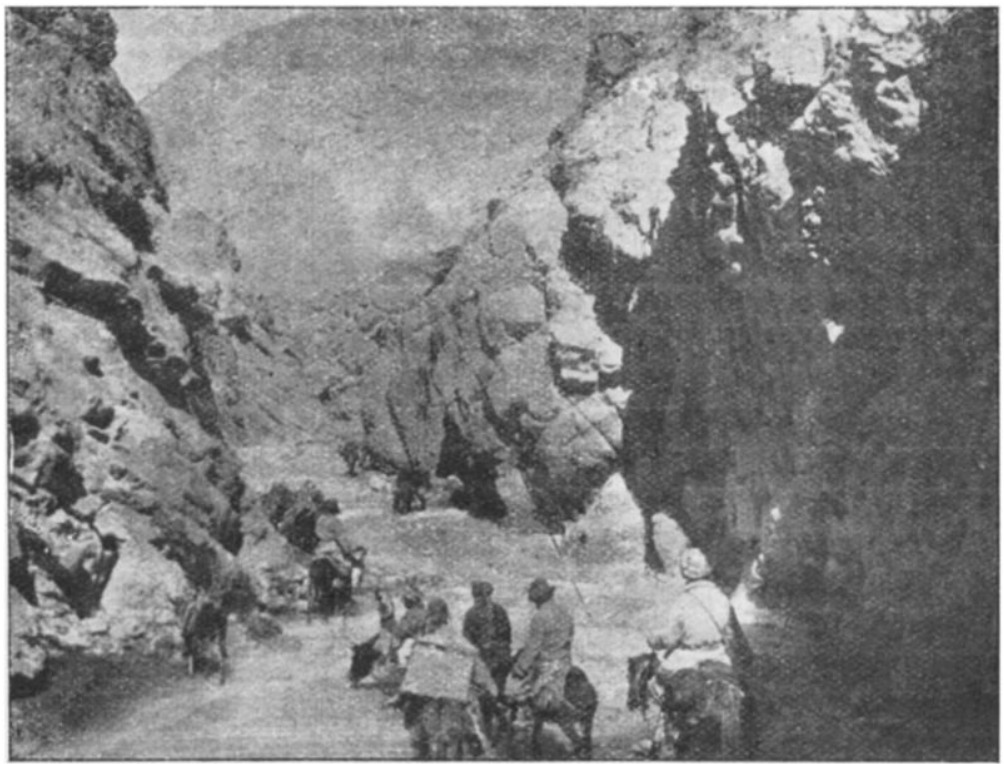

CROSSING THE FROZEN STREAM IN THE KUEN LUN GORGES.

equally steep hills raise their rounded tops another 400 to 500 feet on either side.

The gorges are void of all vegetation, and are wild and rocky to a degree. The descent into them and ascent is at times difficult, being down a zigzag tract just fit for pack-animals. In volume of water there would seem also considerable variation in these streams, but this is mainly a matter of catchment area in their upper sources. As we crossed them in November they must have been almost at their lowest; most were dry or frozen up. Some carried a mere trickle of water, and the remaining three or four were never so much as a foot deep. When in flood, as occurs at the spring snow-melting, they become, on the contrary, wild torrents whose volume is plainly to be seen in the huge 
boulders carried down, and the gravelly soil or worn rock which at times form their sides and bed. As the streams descend into the lower and more open slopes, the gorges diminish in depth and the beds open out. Before reaching the sand of the approaching desert, in most places a wide bare glacis composed of very fine gravel has to be crossed. This formation is lucally known as Sai, and during the passage across it of such streams as are not already absorbed, the channels spread out, as is the case immediately south-west of Nia, to a width of, at times, 2 to $2 \frac{1}{2}$ miles. Practically there is no channel, the flood water pouring down in numerous wide shallow branches. The third and final stage in the life of these mountain streams is reached when those which remain enter the sands of the desert proper, for their fate is then sealed. Local conditions enable some to continue the hopeless struggle a little longer than others, but the tombstone of all, if it may be so expressed, is eventually a marsh where only the last signs of dead and dying vegetation remains.

At Achan we turned north to reach Cherchen, in order to descend the Cherchen Daria, which we proposed to follow to the point where it enters the Kara Koshun marshes. Some slight variation had later on to be made in this plan, and after quitting Cherchen we left the river about halfway down to make for Chakalik, the main oasis of these parts, and so situated as to be of no little importance geographically. Cherchen is the Charchan of Marco Polo, and is referred to by him as the capital of a district of the same name where "there are numerous towns and villages." In the present century we are now beginning to inquire where all these towns and villages are, for Marco Polo has long been proved to be a truthful man, and we find, as Dr. Stein has shown, and is even now continuing to prove, that they have almost all succumbed to the slow but remorseless attack of the desert sands. Whether these latter will be found to cover the buried treasures Egypt and Persia have yielded remains to be seen, and is unlikely, but it may with confidence be said that they have yet to disgorge a wealth of historical and perhaps ethnological remains to the intelligent explorer with time and energy to give to such an enticing task.

The Cherchen of to-day is a mean place of one rambling street, 150 to 200 yards long, with some wretched shops representing the usual Asiatic bazar. The people looked poorer and more unkempt than at any previous village we had passed, and the whole oasis has only an area of some 6 miles by 3 . Old Cherchen stood $2 \frac{1}{2}$ miles south-west of the present site. There are considerable remains, and close to them is an ancient yet clearly marked river-bed with all the appearance of having been formerly a channel of the Cherchen Daria. From Cherchen, in order to keep on fresh ground as far as possible, we kept the right bank of the river until we quitted it.

Between Cherchen and Chakalik the country traversed is composed 
of low scrub and strips of decaying forest, with, nearer the river, miles of reed jungle in which semi-stagnant or salt lagoons frequently occur. Animal life was here once more met with. The Mongolian or Prjevalsky's gazelle were not uncommon. They are locally known as Juggran. Maral stags and wild boar are also common, and the season when the tigers are most in evidence was just approaching. North of the river the sand dunes of the desert are seen close to the left bank, where they rise to a height of 30 to 35 feet.

A feature of the right bank of the Cherchen Daria is the number of disused ancient river-beds we crossed. One we camped in had a depth of 15 to 20 feet, with a width of 90 to 120 feet. The banks were lined with splendid old Tograk trees (poplars), whose age must, from their appearance and native tradition, run to hundreds of years. Sven Hedin has remarked upon the possibility of deducing the time when these channels held water from the age and state of decay of these giant trees, and no doubt they can and should help to determine such questions. What is perhaps of more interest is the fact that the Cherchen river, which still continues to flow, has in times past so often changed its channel, for after-experience proved to us that the marshes and lakebeds of this region have undoubtedly done and are still doing the same. The interest connected with this fact is chiefly based on the effect it may have in throwing additional light upon the yet unsettled problem of the situation of Lob Nor itself.

Even were time available to-night, the subject is one I should hardly venture to touch upon, so entirely has Sven Hedin in later years made the subject his own. The opinions of Prjevalsky, Richthofen, Kozloff, and others are well known, but in view of the scientific interest involved in the question of the inconstancy of all water channels in this basin, I may perhaps be allowed to quote one other case.

About lat. $94^{\circ}$ E., on the Chinese side of the Kum Tagh desert, we explored a wide expanse of lagoon and lake known on our maps as Kara Nor. Here all the signs necessary to substantiate the inconstancy of such areas are very clearly marked. No two people who have examined Kara Nor and its ramifications would disagree in saying that both in area, depth, and actual position it never, for any length of time, remains constant. I venture to think no one who has seen that district, and is acquainted with the minute proofs to which Sven Hedin has put his theory, will again deny that not only Lob Nor, but the whole Kara Koshun basin wherever small lagoons and depressions exist, is in the same state.

It has been said that the geographical position of Chakalik is one of some importance, and a glance at the map will make this plain. The village, for it is no more, stands at a point where four routes meet, and though the traffic on any one of the four is insignificant, as we count it in Europe, it is none the less steady, and each track serves, as all tracks 
in the East do, as a means of disseminating information slowly but surely over very wide distances. The first and most important is kept up between Chakalik and Urumtsi, the capital of the Hsin Chiang. This track runs via Kurla down the Tarim river. The continuation of it south from Chakalik is equally important, as by it all the Buddhist pilgrims making for Lhasa from Central Asia enter Tibet over the Altyn Tagh.

- While at Chakalik I met and talked with a traveller who had only twelve days before returned from Lhasa, where he had been as guide to a lama who had come from near Lake Balkash, in the Semipalatinsk province in Russia, to make the pilgrimage. Among other items of news from Lhasa, our friend told us that since the Younghusband expedition everybody there wore ammunition boots!

The other tracks from Chakalik are that by which we had approached that place, and a second, though one seldom used, continuing south and east to the Chinese border at Sachu. In addition to these four routes, Chakalik can be reached from China proper across the Kum Tagh desert, and this we had long ago decided to attempt. I have seen it stated, and believe it to be a fact, that the Chinese occasionally make use of this route. We had the greatest difficulty, however, in getting any information about it from the Chinese amban at Chakalik, who implored us not to attempt the desert crossing, saying that we should lose our lives if we did, and that the Korla-Urumtsi route was by far the safest. When, however, the amban saw that our minds were made up, he did all he could to help. He ordered the requisite number of men and camels to accompany us, settled the wages we were to pay, and, in fact, took general charge of the expedition.

Leaving Chakalik, we made for Abdal, a collection of reed huts or Satma, as they are called locally, where some fifteen families eke out a hard existence chiefly by fishing in the marshes. Abdal stands on the right bank of the Cherchen Daria, at a point where that river enters the Kara Koshun. The river is known locally as the Cherchen Daria, though it was described by an old man to me as uniting in itself the waters of four streams, viz. the Yarkand Daria, the Kucha Daria, and the Karasha Daria. Few more uninviting spots can be wished for than Abdal as we found it in mid-winter.

The approach from Chakalik is over a waste of sand-dunes and hollows covered with reed-grass. Dotted over the waste are bits of dead forest and huge root-heaps buried in sand. These mounds-like gigantic mole-heaps-are a feature of the southern edge of the desert, and are due to the action of the wind and sand on the vegetation whilst the latter was in course of being overwhelmed. Nearer Abdal the low jungle changes to open sandy hillocks devoid of all vegetation. Only the dead root-ends of brushwood stick up in a mournful way through the sand. A shallow lagoon, 2 miles wide, and various small lake-beds 
show signs of lately holding water. The last 5 miles is across the most desolate, forsaken-looking waste imaginable; not a tree nor a blade of vegetation exists as far as the eye can reach. The surface of the ground must at certain times become a marsh. It is composed of rough heaps of mud and frozen earth. At Abdal the Cherchen Daria was frozen 5 or 6 inches thiok. To the north, north-west, and north-east stretch the dreary-looking marshes with open bits of water which make up the Kara Koshun.

The crossing of the Kum Tagh desert appears to have been an undertaking even in the days of Marco Polo, at which time there is no doubt

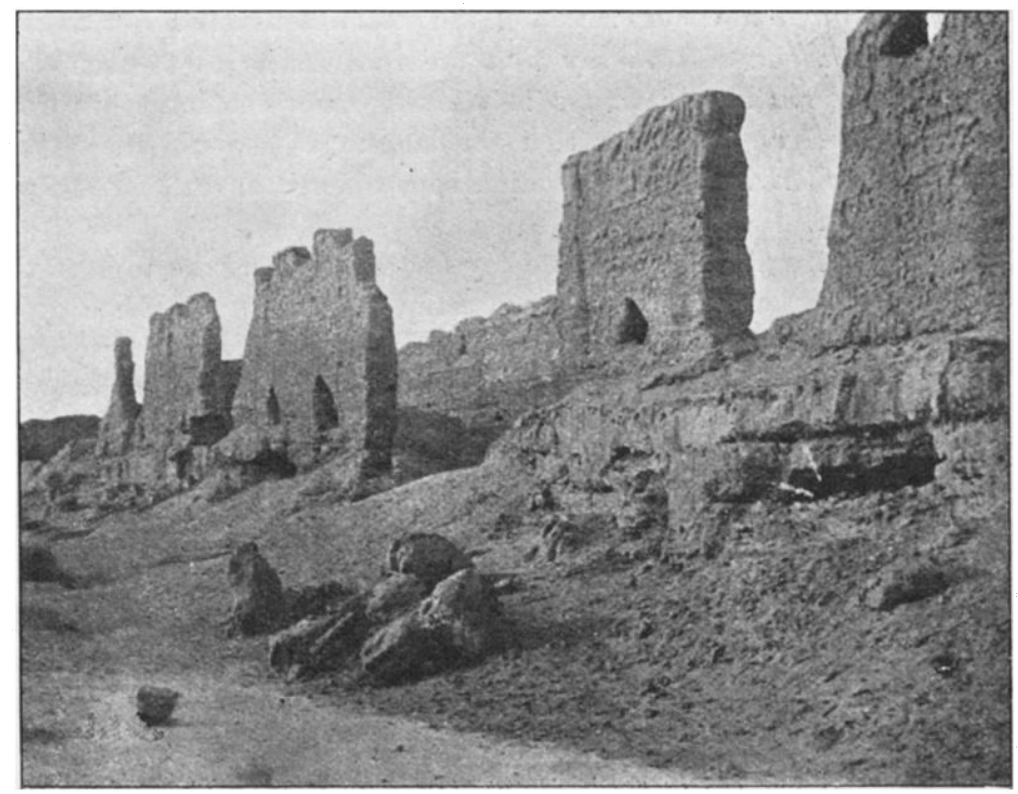

ANCIENT REMAINS OF FORTIFIED POST (KURGAN) NEAR KARA NOR.

a highway of a kind did exist. Whether this highway ran viâ Leu Lan to Sachu, or further south, yet north of Lob Nor, is an undecided point. The description given of it by that wonderful traveller in the thirteenth century is chiefly confined to a mention of the unseen terrors and the evil spirits said to inhabit the desert. "Here," he says, "where its breadth is least, it takes a month to cross. 'Tis all compased of hills and valleys of sand, and not a thing to eat is to be found on it. . . . Beasts there are none, for there is nought for them to eat. But there is a marvellous thing related of this desert, which is, that when travellers are on the move by night, and one of them chances to lag behind or to fall asleep or the like, when he tries to gain his company again he will hear spirits talking, and will suppose them to be his comrades.

$$
\text { No. VI -JUNE, 1907.] }
$$


Sometimes the spirits will call him by name; and thus shall a traveller ofttimes be led astray so that he never finds his party. And in this way many have perished. Sometimes the stray travellers will hear, as it were, the tramp and hum of a great cavalcade of people away from the real line of the road, and, taking this to be their own company, they will follow the sound; and when day breaks they find that a cheat has been put on them, and that they are in an ill plight. . . . And sometimes you shall hear the sound of a variety of musical instruments, and still more commonly the sound of drums. So thus it is," he ends, "that the desert is crossed."

Quaint as the above reads, and little information as our traveller offers of the physical configuration of the desert east of Lob Nor, it will not be without interest to say that the remarks as to the sound of musical instruments and drums may have some foundation in fact, especially when we remember that the language he would use is that of the East, where slight exaggeration is considered an art, not a fault as in the West.

After quitting Abdal our route lay for a day along the edge of the marshes, everywhere frozen. To our camp that night on the edge of the ice weird sounds came floating from the marsh, which were, of course, nothing but the groaning and booming of the ice as it froze. Not being an Asiatic, I should describe it as the far-distant sound of trumpeting elephants, but Marco Polo's description is the more poetical of the two.

Between Abdal and Sachu the passage of the desert took us twentyseven days. The chief difficulty is the lack of fresh water, but in winter this difficulty can to some extent be overcome by carrying ice. Not only did we depend on this at times for our water, but when there was no brushwood or not sufficient to enable us to make a fire to melt the ice for them, the animals were also fed on lumps of ice broken small, if fed is the right expression. The other difficulty is the lack of adequate grazing, and it was due to the want of food as much as to the general exposure that our animals began to succumb before we reached the farther edge of the desert. From the point of view of physical geography, the eastern end of the Lob Nor basin offers most interesting and convincing evidence of the theory that the whole basin was once a vast inland sea.

In the desert two days' east-north-east of Abdal our track struck the foot of sandy cliffs having buttress-like faces fronting to the north 35 feet in height, covered with gravel on the top. Along the foot of the cliffs runs a narrow strip of reed vegetation 30 to 40 yards wide, in which marshy spots are found, the water sometimes fit to drink, but usually not. After following the line of cliffs for a day, our guide struck away from them north-east into the bare desert, where there is no sign of vegetation, the surface being of the nature of the bottom of a pond 
frozen hard as it dried up. It stretches thus to the horizon, except towards the east, where as far as the eye can reach the cliffs appear to run on.

On the following day our track once again ran under another line of cliffs, of the same kind as the first, but more to the north and higher, their scarped front being in places 60 feet above the desert. Continuing along the base of this second sea-shore, the cliffs became gradually less regular. Isolated hillocks like islands pushed themselves forward out into the desert, and later the same day, having quitted the shore-line and followed a course east-north-east, we once more struck a third and equally well-marked sea-coast, but this time our course lay along the top of a line of cliffs almost identical with the two previous ones.

On Christmas Day, 1905, our camp was pitched under a steep bluff in the face of the cliffs. As it happened, the formation of the various sand strata composing the cliff-face was very clearly marked at this spot, so our holiday was spent in making a careful section of the exposed face. For the next two days we maintained the same direction, viz. northeast and east-north-east uniformly, every day more strongly confirming the impression that we were travelling along the southern shore of some huge island sea. So strong is the impression, that it is impossible to describe this portion of the desert in any other language than that which would naturally be made use of were this the case. On the tenth day from Abdal, the character of the sea-shore begins to change somewhat. The lines of cliff give place to stony ridges, with here and there rock outcropping. The ridges, like the cliffs, are not of loose sand, but are of hard-pressed clean-cut sand, as if built. The surface of the desert here resembles a field which has been newly steam-ploughed, then frozen hard. The going is as bad as it could be.

Here for the first time since Abdal, the boundless horizon to the north was broken in the far distance by an indistinct line of hills. In this part of the desert water is an even greater source of anxiety, as we had invariably to dig for it, sometimes as deep as 8 to 10 feet. The result was usually a few inches of liquid of a kind, and for that, when it came, we were thankful. At other times good water-holes were discovered, one of the best on the last day of the old year, and as there were also some reed-grass and dried-root heaps, we decided to rest the animals on New Year's Day. Though in itself an insignificant matter, the formation of these dried heaps is of the utmost importance to travellers in the desert, for they afford the only fuel obtainable. The root-heaps near Abdal already referred to are found on a much smaller scale in the desert, and I venture to offer the following theory of their formation: They may be said to exist where marshy spots or springs are or have once been. Each bush drops its fronds, when dead in the autumn, directly into its own roots. This continues year after year, and each storm, or even the 
ordinary high winds, blow the sand more and more into and on to the bushes. As the sand covers the fronds heaped at the roots and mixes with them, it so gradually turns them into the bush sand-heaps, which, while the bush still lives, have only the tops showing. When the bush is dead and the ceaseless struggle with the overwhelming sand is finished, the latter spreads over the top of the bush, from which, if one digs into it, roots may yet be brought up to form excellent fuel.

After the rest to our animals on New Year's Day, I was able the following one to temporarily quit the caravan and ride to the base of the northern range, the approach to which was found to be of the same character as that to the lower Kuen Lun ridges further west. The range itself rises precipitously to a narrow rugged ridge, and is composed of hard clay or mud, probably with sand below. There is no vegetation whatever. The general average of the range was under 800 feet above the level of the desert. The direction lies east-north-east to west-southwest, and it can only be one of the southern ridges of the Kuruk Tagh, but which, such maps as we possessed of this region led us to suppose, did not come nearly so far south.

After passing this spot, clay terraces and isolated hillocks, which have all the aspect of ancient ruined cities, but are really mounds of clay, become the feature of the desert on all sides. These mounds are of the most fantastic shapes, and have been worn into such resemblance to ruined walls, towers, and gateways that, even close at hand, one at first imagines they represent the ruins of long-lost settlements. The surface of the desert now consists of a series of depressions, separated either by rolling ridges of hard fine gravel, or divided from each other by clay terraces. Under the firm gravel the soft sand is still to be found, with a few sand-heaps dotted about. The faces of some of the terraces are cut into curious shapes by the action of the wind. In one place the northern side has been worn into a line of what looked exactly like gigantic tombstones.

Twenty days from Abdal we camped by a good water-hole in one of these local depressions, finding, much to our surprise, a clearly marked ancient river-bed, in which were a quantity of growing reeds and some brushwood. Leaving this camp, we were again astonished by suddenly coming upon an ancient watch-tower, or torla, the first sign that we had struck one of the old historical highways which are known to have been kept up by the Chinese centuries ago. A few miles east of this point, in lat. $40^{\circ} 21^{\prime} 37^{\prime \prime}$, commences what has been, and may at any time again be, the western end of Kara Nor, the lake already referred to.

The night we reached the edge of this lagoon was, unluckily for us, marked by one of the terrific storms locally called kara buran (black storm). We had turned in after a long march on foot, and were hardly into our bags before the storm broke over the camp. Anything like the force of the wind we had never before experienced. 
Luckily, the tents were under a gentle rise, and made fast fore and aft to some small trees; the pegs, also, as was our custom, were anchored down by the yakdans placed on top of them. For five hours the tents swayed and rocked like boats at sea, threatening every moment to be blown clean away, and all that could be done was to cling tightly to the front pole, hoping that the additional weight might prevent the final catastrophe. The storm burst in mad gusts about 9 p.m., blew its hardest about 10 p.m., and, as we foolishly imagined, appeared to be subsiding at 11 p.m. Feeling the wind going down, we ventured to quit the tent-poles and to exchange confidences as to the damage so far as we could make ourselves heard. Hardly had we crept back into our

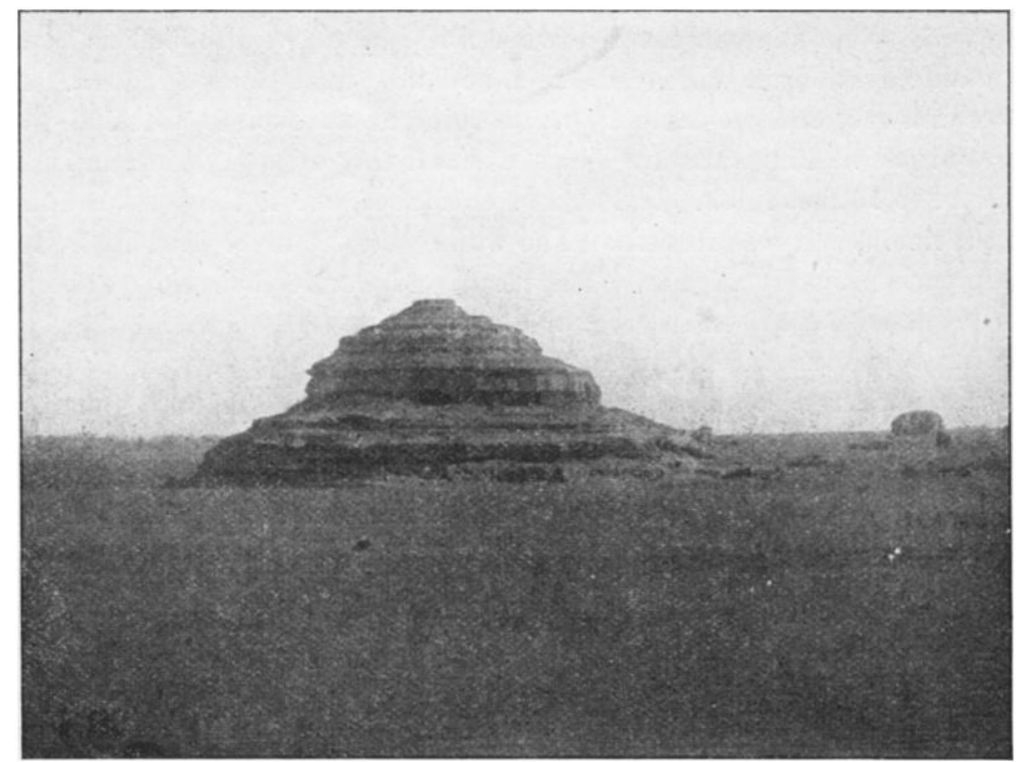

A NATURAL CLAY TOWER IN THE KUM TAGH DESERT.

rugs and gone off to sleep when we were once more awoke by the same terrific gusts and wild shaking of the tents. There was nothing to be done but to jump out into $25^{\circ}$ of frost and again hang with all our weight on to the tent-pole. For another two and a half hours the gale raged, until we almost began to despair of keeping the wind out. Had the door-fastenings given, or one gust managed to get in, the whole tent would have gone. Luckily, neither of these things happened, and by half past 2 a.m. it was safe to creep back once more on to one's rugs, and this time for what was left of the night. Waking in the morning, there was no sign of wind or storm, and but for layer upon layer of fine sand which had penetrated everywhere, the whole kara buran might have been a nightmare. 
In the morning we explored the lagoon, finding along its southern border the remains of another ancient watch-tower, one of a series of four visible from that point. The watch-towers are some 2 miles apart, well placed to be seen, and on a line nearly west and east. The first watch-tower is built of mud or clay bricks, between which are layers of reeds. It had a base some 30 feet square at the bottom, and 15 feet at the top. The entrance must have been by ladder, or, as is still seen on the watch-towers in north-west Kan-su, by a very slender stairway up one wall outside. This stairway is also of brick, but can be destroyed in a few minutes once the defenders have mounted.

Five miles to the north of the lagoon the spurs of the nearest Kuruk Tagh can be seen. During the following day, having crossed an undulating wind-swept plateau covered with fine gravel, we dropped as usual into a depression, in which has been and now is at times a lagoon. At the south-east end we came upon the ruins of an ancient fortified post (or kurgan). The walls are built of small clay or mud bricks, and are still 14 to 16 feet thick. It had two entrances, one to the west, another to the north, and was roofless. The walls were 20 to 25 feet high, and were once probably nigher. The post is of wonderful solidity, and in its day must have been impregnable.

Later on the same day another kurgan was discovered, but this was of larger dimensions, and probably held a permanent garrison. The remains of the double walls are 80 yards long by 50 wide outside, the inner walls being some 30 feet above ground-level. The site overlooks a wide-spreading lagoon 8 to 10 miles in extent, the bed of which held little water, being filled with reed-jungle and clay mounds.

For the last few days in the desert our route lay over the same kind of country as that already described. Even right up to the border of the oasis surrounding Sachu vegetation is exceedingly scanty, and the first sight of trees, luxuriant to us after the last month, was a real treat. Sachu is an ancient Chinese settlement said to have been planted as an outpost against the marauding Hung nu, or Huns (?), as early as the first century A.D. It was originally called 'Tung Huang, and is at present known locally by no other name.

From Sachu to the Great Wall at Chia-yu-kuan, the ancient frontier of China, took us twelve days to march. Here the final portion of the journey commenced-that through China proper. Though still three months from our destination, we were for the first time for six months in touch with civilization in the shape of the telegraph. From here to Lan Chou, the capital of Kan-su, the main great north-west road from Peking to Kashgar was traversed. The country, though sparsely settled, is of considerable value, being well adapted for pastoral use. Unfortunately, the Chinese are not a pastoral people, being essentially agricultural, so that it is unlikely that any large immigration will take place. 
'The mineral value of this portion of China is considerable, and I venture to prophesy that in the not far distant fnture it will make a name for itself as one of the richest coal and oil districts in the country. At present its future exploitation, from the point of view both of trade and mineral wealth, depends entirely upon the construction of a railway.

This strip of north-west Kan-su is, in its physical aspect, a continuation of the series of oases which border the desert along the northern base of the Kuen Lun range in Chinese Turkestan. Its streams, such as they are, partake of the same character as those already described in the latter country, that is to say, they are snow fed from the Nan Shan range and its offshoots, and are of variable volume, with a short course which ends in absorption in the desert to the north, or they are merged in the waters of the only two rivers deserving that name, the Hei Ho and the Yellow river. The main watershed dividing these two streams is formed by the Wu-shi Ling, a pass just under 10,000 feet in height, which presents no serious difficulty even to wheel traffic.

On the southern side of the Wu-shi Ling, a marked difference is tc be seen in the agricultural wealth of the country. From the Wu-shi Ling to Lan Chou, in a minor degree, are found all the characteristics common to the more settled provinces of China. Here the population per square mile at once begins to increase. Villages are more thickly planted, and the general aspect is one of agricultural comfort.

From Lan Chou to Tai-yuan Fu, in Shan-si, our route lay through a little-known part of China. We crossed Eastern Kan-su Shen-si an Shan-si provinces, between the 36 th and 38 th parallels of latitude, visiting villages and old towns where Europeans had in some cases never before been seen. The area traversed consists of a series of plateaux in the heart of the loess country of North China, whose average height above sea-level is nearly 4000 feet. As is well known, the loess country is a most fertile soil, but more than any requires water, and that without fail. The districts traversed, though thinly populated, support a larger population than is usually supposed, and afforded a surprise in the character of the country, such as must be seen to be believed.

A study of the loess formation of Northern China would afford sufficient matter for more than one paper such as this, and it is only referred to to-night in the hope of invoking some information upon what appeared to us a matter for surprise, nowhere having previously seen any reference to such an extraordinary change in the character of the loess soil. The arid aspect and monotonous lack of natural vegetation common to all such districts is well known. Traversing the intricate network of valleys and stream gorges, between which are the plateaux characteristic of this part of Northern China, we had reached the border-line between Kan-su and Shen-si.

Beyond the town of Ching-yang $\mathrm{Fu}$ we were suddenly surprised, in the course of the day's march, to notice the valley-sides and hills were 
becoming covered with brushwood. As we ascended the valley up a small tributary of the Huan Ho, trees, grass, and undergrowth increased, and the face of the country began to change as though by magic. The stream had become so choked with brushwood as to be almost impenetrable, and though the effect was somewhat sombre owing to the foliage not yet being out, the relief to the senses after the unvarying drab-coloured hill-sides and terraces was most pleasing. Towards midday we had mounted some few hundred feet up a spur on to a main ridge, and from there the view to us seemed a fairy transformation. Impossible as it may sound, but for the lack of grass, it was easy to imagine one's self riding over the Surrey hills. A series of ridges and spurs divided by numerous small valleys lay before us, all heavily clothed with trees and thickets of thorn and other scrub. As far as could be seen around, the whole district appeared similar, and it was easy enough to believe now the stories we had heard a few days previously at a tiny Catholic mission station buried in these wilds, of boar, deer, panther, pheasants, and game of all kinds. The existence of this mission was quite unknown to us, and it was by accident only that we did not pass without seeing it. Riding ahead of the caravan through the ruins of what had once been a picturesque village, Ma-Lin by name, I had paused to admire one of the lonely stone memorial arches so common in China. In addition to a low balustrade, the front of the arch pillars was faced with polished black stone, upon which was graven deep Chinese characters. From the tops of the fretted grey stonework hung small bronze bells, which the gentlest breeze sufficed to set tinkling.

Previous to entering the village we had passed the remains of a picturesque old temple, and no doubt the latter, as well as the archway, were both part of the same story could we have learnt it. Inquiry, however, as was usually the case, proved fruitless. In China, those able to do so are never anxious to tell the story.

As I was about to move on, my eye caught sight of a Chinese farm hand, and on looking at him again I was astonished to see in his mouth a distinctly European pipe. At the same moment I noticed, over the doorway of one of the courtyards, a small cross. The mystery of the pipe was soon explained. In answer to my question, the owner of it led the way into the yard, on the other side of which stood a tiny chapel, from whence, as we entered, one of the. two brothers in charge was just emerging. Mutual introduction followed, and we were soon enjoying the limited but unstinted hospitality the little mission afforded. Buried in the wilds of Kan-su, this has been established for fifteen years. So far as the two brothers were aware, it had only twice before been visited by strangers. In one case the traveller was the well-known mission leader, Dr. Martin; in the other it was the Russian explorer Obrutchev. 
Thanks to the artistic powers of a former brother, the mission possesses a perfect gem in its miniature chapel. Inside it is profusely ornamented with scroll paintings of no mean merit, and these, with the carved woodwork in which Chinese carpenters excel, and some imported lanterns, give to its interior an aspect of tender care wholly in keeping with the character of the devoted men who are content to spend their lives cut off from civilization.

After bidding farewell to our hosts, we crossed into Shen-si province, and made our way over one watershed after another by hill tracks until we struck the valley of the Lo Ho at Fu Chou. Up this we turned to Yen-an Fu. A curious feature of this district is the cave tombs to be seen here and there cut in the solid rock. That they are or were temples I believe to be the case, though I am aware that during the terrible days of the great Mohammedan rebellion many caves were used as hiding-places by the wretched inhabitants.

From the solidity of the work, and in one case from a curious kind of sarcophagus which we saw in a temple, I am led to suppose that they are Buddhist remains. That Buddhism still flourishes is shown by the temples in daily use. Most picturesque some of these are, and I was fortunate to be the witness of a quaint scene at one of these lonely spots. A little temple stood perched on a rocky bluff some 40 feet above a small stream having at its back a steep thickly wooded hillside. As I rode past on the narrow winding track, a respectably dressed farmer had just arrived, either to return thanks for some favour or to ask a boon from the little gilt figure of Buddha, which sat enshrined in the usual attitude. Having dismounted, the farmer produced from his saddle-bags six large dough-cakes, an offering which visibly caused the mouth of the old priest to water, and as the latter, an old man, kept solemn time beating a small brass incense-pot with a tiny mallet, the farmer made his prayers and his adoration on his knees. Holding in one hand a lighted fire-stick, he lit two small pieces of tissue-paper which lay in his right palm, then gently allowed the burnt ashes to float away. Rising from his knees, he turned to me as I sat outside on my mule, and politely asked if the noise of crackers would frighten the animal, at the same time holding up a josspacket which he took from a table by the door. As the mule was standing on the very edge of the bluff above the stream, I replied that probably it would, so he quietly bade me depart, and I went, but for the rest of the day I could not shake from my mind the idea that in the simple ceremony just witnessed perhaps the key was to be found for the regeneration of this vast empire, which before everything requires a firm and honest belief in some moral faith.

Near Yen-an Fu the first signs are met with of the vicinity of the huge coalfields which cover Shan-si and stretch well into Shen-si. Petroleum is also found 30 miles from the town. Yen-an Fu, like Chingyang, is merely a skeleton of what it once has been. Ichabod is written 
large over all these towns, which have never rallied from the years of continuous warfare which the first Mohammedan rebellion inaugurated. It stands on a small tributary of the Yellow river, the Fu Ho. None of these streams are navigable, not even the Lo Ho, which we had crossed at $\mathrm{Fu} \mathrm{Chou}$, although at certain seasons the water is deep enough to allow of the passage of the flat-bottomed ferry-boats in use on the Yellow river. Most of the streams are too winding and the mud-banks and shallows too frequent to make it worth while to attempt navigation.

Leaving Yen-an Fu, we struck north-east across a local watershed to Yen Chuan, a small town standing on the Hsia Ho, a tributary of the Yellow river. The approach to the latter is through a most intricate network of small ravines and rocky gorges, though still the general character of the country is loess. At the point we crossed the river by a ferry is the tiny village of Yen-shui-kuan. The left bank has a precipitous cliff of rock 180 to 200 feet high, the right being much lower, and from it broken low hills run back, under which the village nestles at the water's edge. The river is 300 yards wide and flat bottomed; plank-built boats carry on the local traffic down-stream.

The western half of Shan-si province is similar to the Shen-si country, that is loess, but with the unusual red-coloured formation occasionally showing up. This is said by Richthofen to occur where the loess lies in greatest thickness, its lowest portions then being of a reddish colour. Once across the Yellow river, the traveller finds himself gradually approaching a veritable black country, where coal, and coal alone, occupies the lives of three-quarters of the population.

Historically, Shan-si province may be said to represent the home of the Chinese race. As early as B.c. 2255, the people of Meaou, who were the inhabitants of what is now called Shan-si, are mentioned in the Chinese classics as being in a state of rebellion. From the same source, we know that the Yae-Yuan plain mentioned as being "set in order" after a great flood (probably the flood referred to in the Christian Bible) is that portion of the present Fen Ho valley between Fen Chou and Ping-Yang in Shan-si.

At Fen Chou the main highway from Sian $\mathrm{Fu}$ to Tai-yuan $\mathrm{Fu}$ was reached. The town lies at the north-west end of the Huo Shan, a high range which is the dividing-line between the anthracite districts of Eastern Shan-si and the bithuminous portion of the province lying mainly to the west of the mountains.

Tai-yuan Fu, the capital of the province, lies on the left bank of the Fen Ho, and is chiefly known to ill fame as being the scene of the most cold-blooded and brutal murders of European missionaries in 1900. Between Tai-yuan Fu and Cheng-ting Fu, the latter a station on the Lu-Han railway which connects Peking with Hankow, some of the richest coal and iron districts in the province are to be found; anthracite coal of the very best kind is mined in unlimited 
quantities, and the strings of donkeys, each laden with two enormous lumps of coal, are a feature on the abominable track over which most of the trade into Shan-si still runs. That this historic route will soon become a thing of the past is probable, for a small branch line has even now penetrated halfway to Tai-yuan $\mathrm{Fu}$, which Belgian interest is responsible for. It is hoped that the capital of Shan-si will be reached in another eighteen months.

Finding the railhead at the small town of Ching Hsing, just inside the border of Chili province, we gladly exchanged our nine months of methodical daily tramp for the speedier and more modern method, and in forty-eight hours found ourselves in Peking.

Before the paper, the President: I have to introduce to you Major C. D. Bruce, who is addressing our Society for the first time to-night. I shall not, of course, say anything about his last interesting and, to a large extent, novel journey through Asia from Leh to Peking, because his paper will speak for itself, but I will say a few words as to his previous career in the Far Fast, which made preparation for that journey. Major Bruce went out originally to Wai-hei-wai as second in command under Colonel Bower-who is here to-night, and I hope will speak later of that Wai-hei-wai regiment of which we used to hear so much, but which no longer exists. In 1900 he went with the regiment on the Peking expedition, and was severely wounded in the attack on Tien-tsing. Since that time he has been travelling largely in Asia. I need not give you the details; but it will interest you to know you are not listening to a neophyte in the ways of the East. I now call upon Major Bruce to give us his paper.

After the paper-

Sir Thomas Holdich: Major Bruce has taken us into a part of the Eastern world with which personally, I regret infinitely to say, I am unacquainted; consequently, I am able to offer but little criticism on the admirable paper he has just read to us. I have just a word or two about the loess formation to which he has alluded, which may be interesting. So far as I know, where I have travelled in Central Asian districts, loess formation is to be found on the northern slopes of all the principal ranges running east and west throughout the country, and I have long ago come to the conclusion that the formation is due partly to wind action (especially to the extraordinarily forcible north-western winds which obtain all through high Asia), and partly to detritus washed down from the hills during the season of flood. That undoubtedly is the condition of the loess which we find on the northern slopes of the Turkestan ranges, and although I am quite unacquainted with the part of Asia which Major Bruce has been describing, I cannot help thinking that the same great forces of Nature produce the same formations which he has encountered. There is, however, another point to which Major Bruce has made allusion to which I should like to call your attention. He has recognized, in a most generous way, the admirable assistance obtained from one of the native surveyors, who was attached to his party from the Survey of India. Now this, I am glad to say, is nothing new, for I think every explorer who has been assisted by these surveyors lately has invariably borne the same evidence to the excellence of their work. But at this time it is with new interest that we regard this matter, for we are approaching a new phase of geographical exploration. The old age of pioneer work has passed away, and we must now, when we set to work to wander through new countries (as Major Bruce has done), make use of more or less trained 


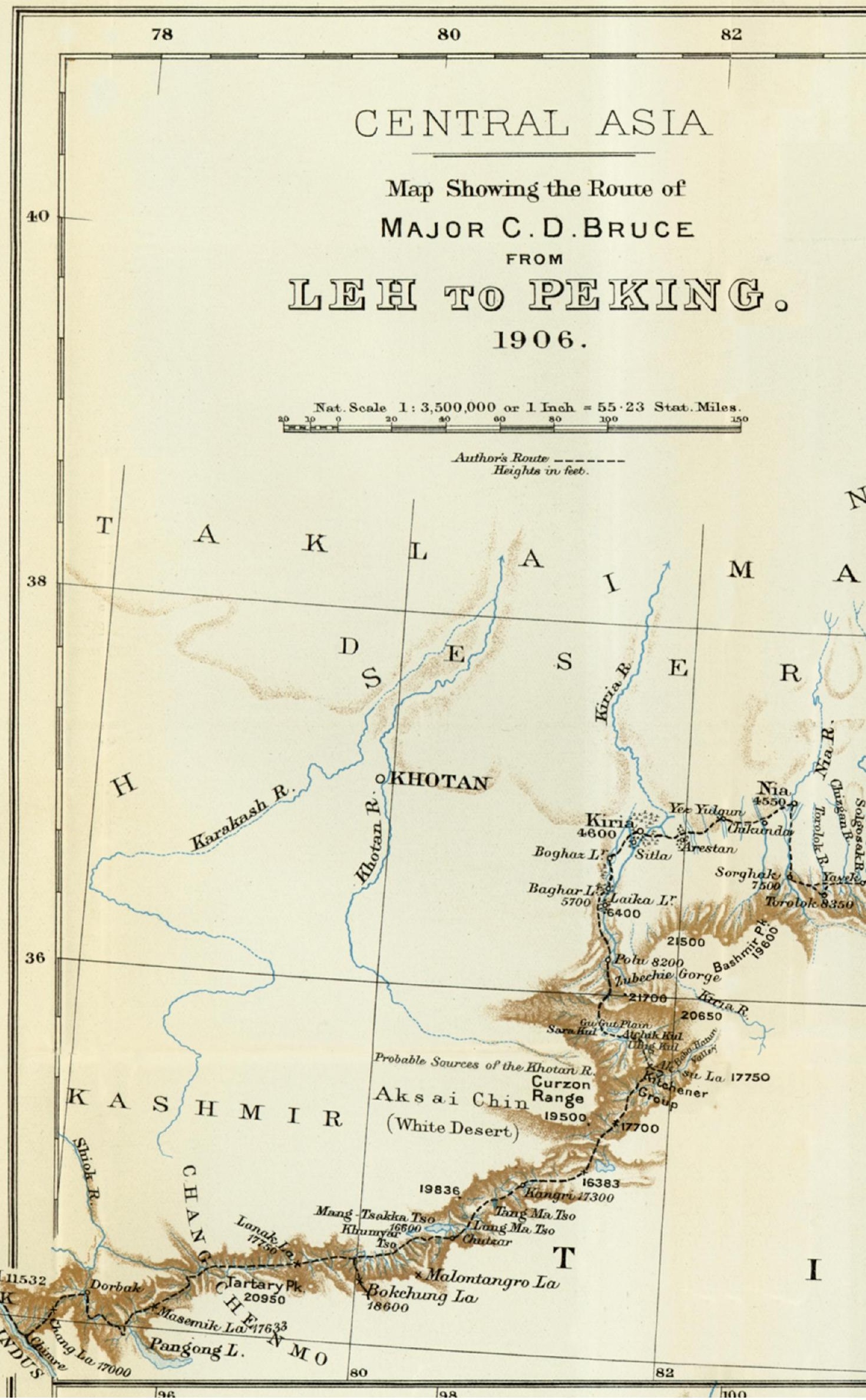

This content downloaded from 128.235.251.160 on Wed, 31 Dec 2014 14:52:20 PM All use subject to JSTOR Terms and Conditions 


\section{6}

88

90

92

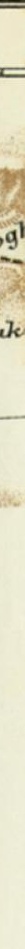

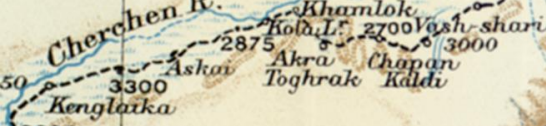
Alsoo

2

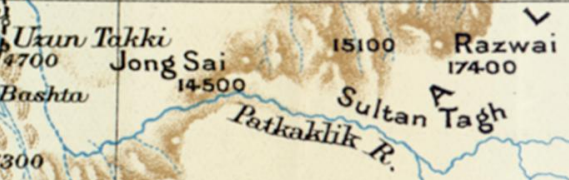

300

18600

oneba Pass

na Pass

E

88

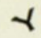




\section{स}

7600

K $\quad T \quad A$

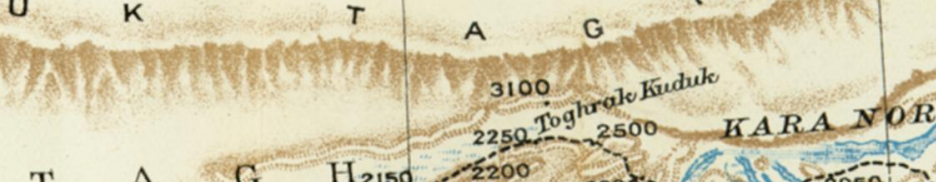

Bulangix $R$.

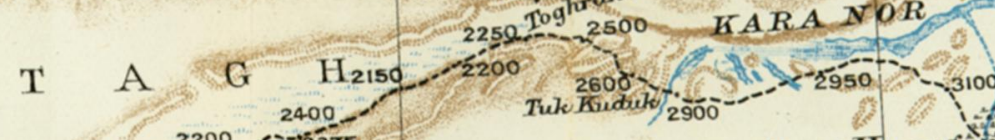

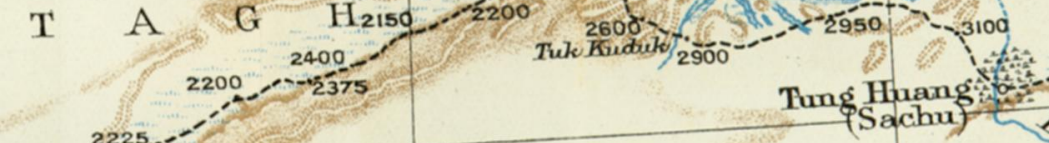

D E S E R T

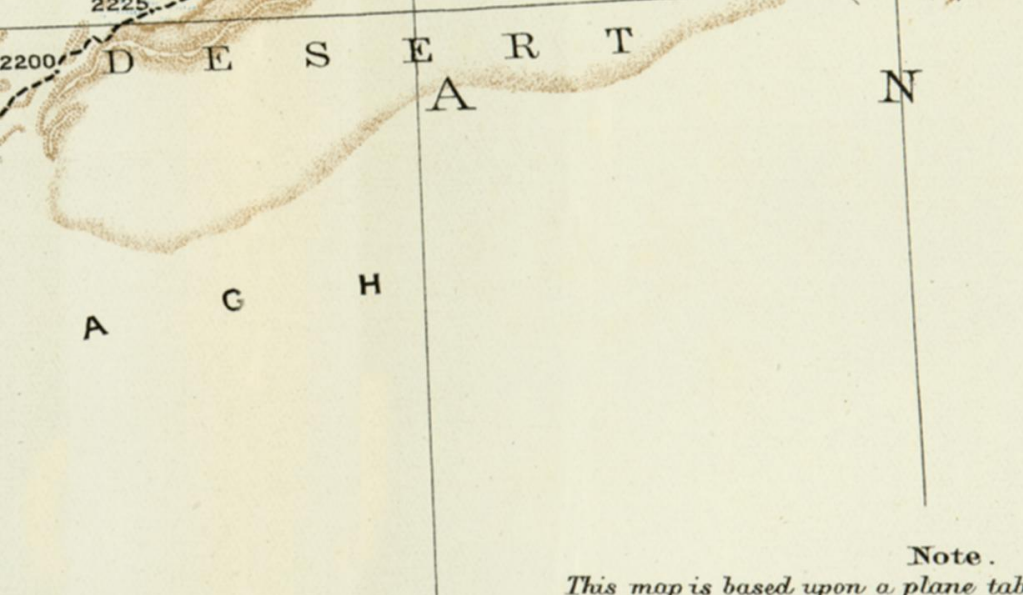

Note. angles taken with a transit theodolite and occasional prismatic compass bearings. Astronomical observations for determining the latitude of positions on the route were usually taken about once a meek, and the results are given in the table below.

The heights are from boiling point and anervid readings, and depend upon Leh. The longitudes are oblained from the route baverse, and must be considered as approximate only.

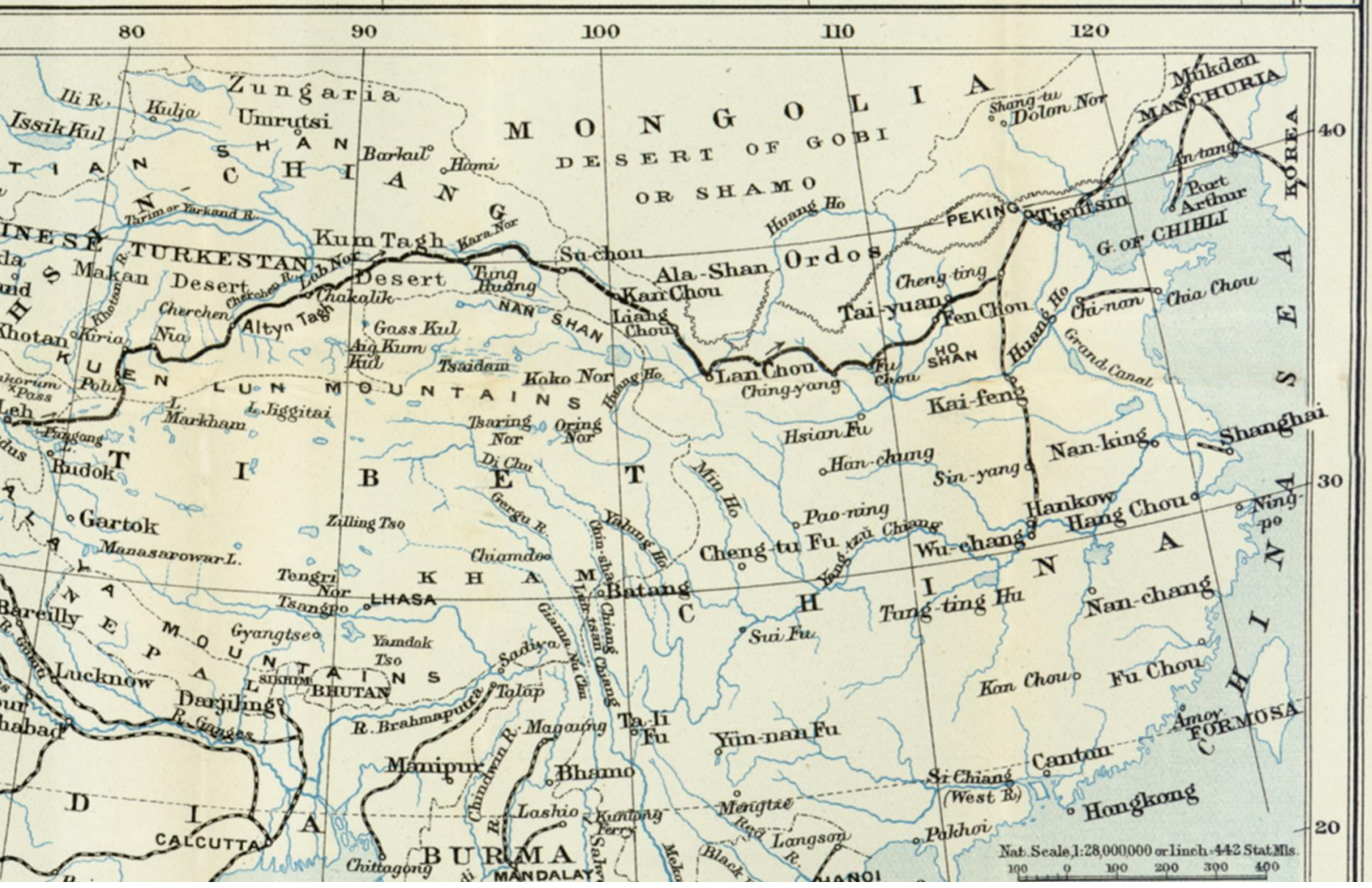




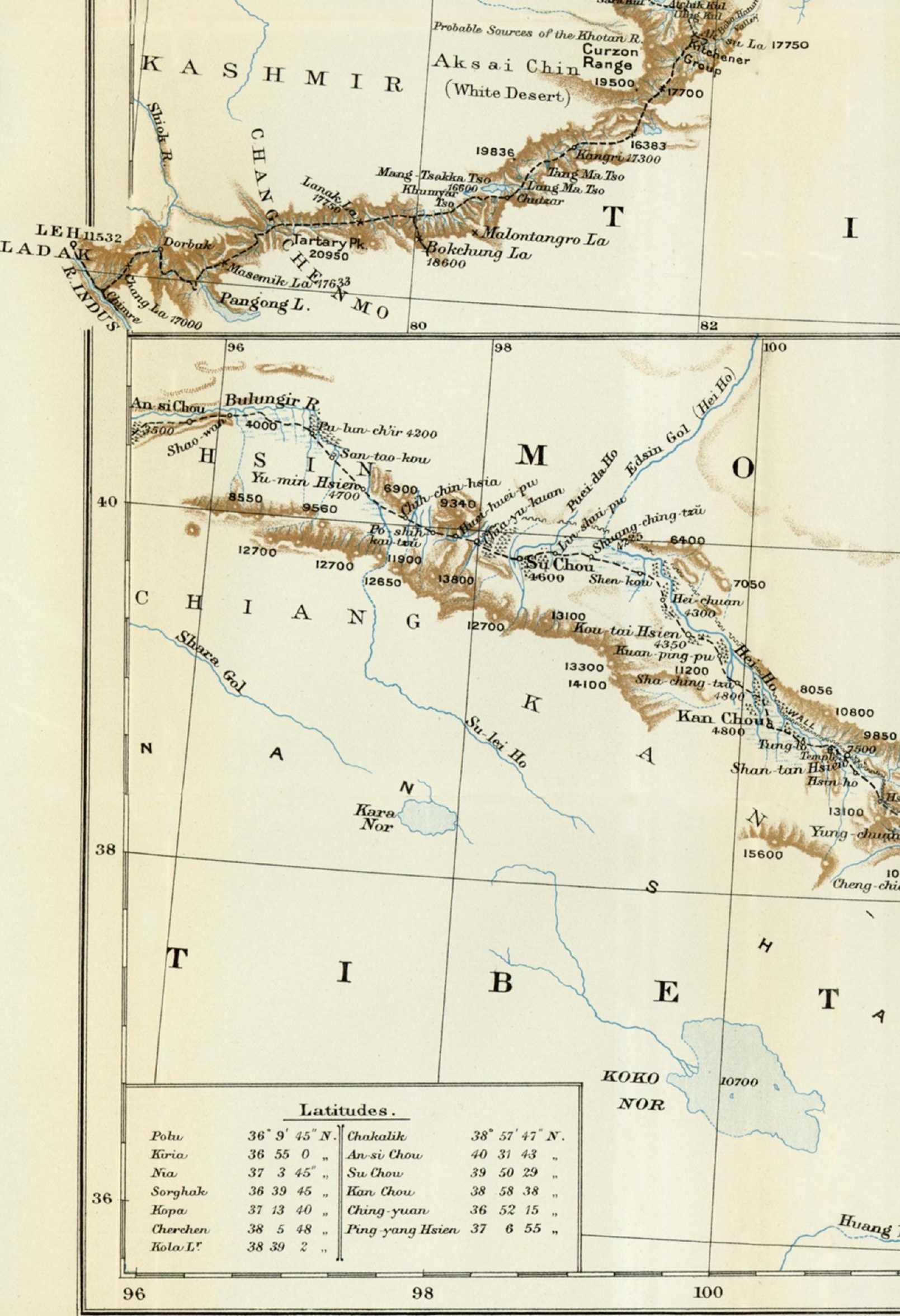

Conical Projection with Standard Parallels $35^{\circ}$ and $40^{\circ}$ 



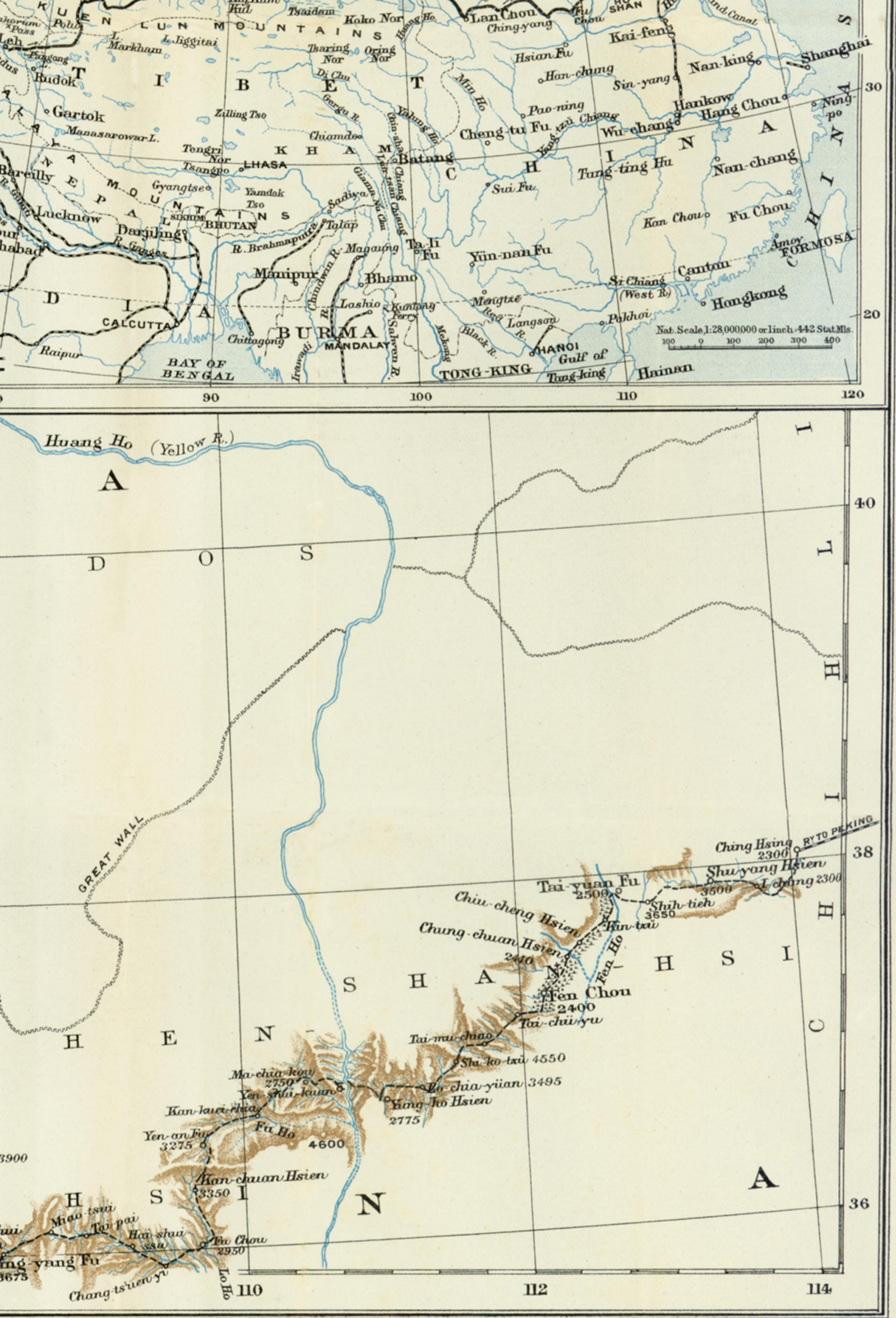

